Ambiances

anbiances Environnement sensible, architecture et espace urbain

$5 \mid 2019$

Phenomenographies. Describing urban and

architectural atmospheres

\title{
How atmospheres inform urban planning practice - insights from the Tempelhof airfield in Berlin
}

Comment des atmosphères influencent des pratiques d'urbanismeenseignements tirés de l'aéroport de Tempelhof à Berlin

\section{Ulrike Mackrodt}

\section{OpenEdition}

\section{Journals}

Electronic version

URL: http://journals.openedition.org/ambiances/2739

DOI: 10.4000/ambiances.2739

ISSN: 2266-839X

\section{Publisher:}

Direction Générale des Patrimoines - DAPA - MCC, UMR 1563 - Ambiances Architectures Urbanités (AAU)

\section{Electronic reference}

Ulrike Mackrodt, « How atmospheres inform urban planning practice - insights from the Tempelhof airfield in Berlin », Ambiances [Online], 5 | 2019, Online since 20 December 2019, connection on 10 December 2020. URL : http://journals.openedition.org/ambiances/2739 ; DOI : https://doi.org/ 10.4000/ambiances.2739

This text was automatically generated on 10 December 2020.

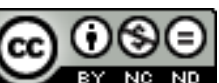

Ambiances is licensed under a Creative Commons Attribution-NonCommercial-NoDerivatives 4.0 International License. 


\title{
How atmospheres inform urban planning practice - insights from the Tempelhof airfield in Berlin
}

\author{
Comment des atmosphères influencent des pratiques d'urbanisme- \\ enseignements tirés de l'aéroport de Tempelhof à Berlin
}

\author{
Ulrike Mackrodt
}

\section{Setting the Stage}

1 In October 2008, the last plane took off at the inner-city airport of Berlin Tempelhof, leaving behind a vast infrastructure site in the middle of the German capital. The question arose of how to use the huge terrain of more than 360 hectares. In a city with a recent history of a significant loss of population and a relaxed housing market, there was no immediate pressure for development. Therefore, the area was opened as a public park and became very popular with the urban public. With the Berlin housing market tightening after 2010, the city government started planning efforts for future housing and commercial development on the fringes of the airfield. These development plans were abruptly halted by a city-wide referendum in 2014, in which the Berlin electorate voted against any developments within the premises of the former airfield.

2 This empirical case - the article argues - offers valuable insight on how atmospheres inform planning decisions. As will be shown, the planning conflict sketched out above between the planning officials and the local population was triggered by contradicting atmospheric perceptions of the former airfield. As Tonino Griffero's example of an oak tree illustrates, a place can be perceived fundamentally differently, depending on the subjective context of each individual.

[An oak tree] is, for instance, a potential few cords of wood for the forester, a threatening daemon for the little girl, to whom the knobby bark resembles the deformed face of a man [...]. The same object, in a strictly physicalist sense, 
therefore presents different tones in different species-typical Umwelten. (Griffero,

2014, p. 32)

In the empirical case presented here, the very creation of landscape plans, maps and zoning decisions made by planning officials heavily relied on their "[a]tmospheric perception [of the airfield as] a holistic and emotional being-in-the-world" (ibid., p. 15). Similarly, the local protesters were affected in their political valuations by the atmospheres they perceived. Strikingly, both sets of atmospheric perceptions had little overlay, promoting the political conflict of the Tempelhof airfield. By empirically focusing on the participants of an urban planning conflict, the article - on a conceptual level - is able to sketch out the societal and political impacts of atmospheric perceptions that go well beyond the scope of the individual subject.

\section{Disregarding the sensing body/subject in urban planning}

4 The very premise of planning officials being accessible to the "unobtrusive obtrusiveness"1 (Böhme, 1995, p. 47) of atmospheres disrupts common conceptions of the planning sphere. As Longhurst (1997) argues, planning theory has been dominated by the idea of "a [emotion-free] mind unlocated in space" (ibid., p. 491). Correspondingly, the self-image of planning officials regularly excludes all emotional expressions: "Planners typically conceptualise themselves as professionals not emotionally engaged with their work" (Ferreira, 2013, p. 703). Rather, emotions are solely considered outside of the planning realm in order to "anticipate and avoid undesirable emotional responses on the part of the audience" (Hoch, 2006, p. 368). Hence, emotions only represent a source of irritation for the 'proper' planning process.

5 This neglect of emotions and feelings in planning discourse resonates with the broader phenomenon in Western society of separating a public and private realm, leaving the field of feeling and sensing to the latter. Hasse (2012, p. 178) describes this maneuver as a

cultivated segmentation of the human being in so-called 'public' and 'private' life segments. As an acting individual one appears to act according to good reasoning in science, administration, law and legislation as well as in daily life. As a sensing quasi separate - human however, one enjoys the art, good food, sports, sees a therapist and enjoys leisure time. ${ }^{2}$

The segmentation described by Hasse clearly resonates with the traditional model of the rational planner in times of modernism (Sehested, 2009, p. 249). Empirically, this concept does not apply to the diverse realm of planning practice anymore ${ }^{3}$. With the rise of the entrepreneurial city and governance approaches to urban administrations, the idea of a rational planner has become obsolete. Consequently, more adequate approaches to planning theory have emerged, such as communicative planning (Allmendinger, Tewdwr-Jones, 2002; Healey, 1996, Sager, 1994) and planning by governance (Nuissl, Heinrichs, 2011; Salet, Thornley, Kreukels, 2007). These turns introduced new theoretical concepts to planning discourse, mainly from social and political sciences, such as Giddens' structuration theory (1984) or Habermas' Theory of Communicative Action (1983). While these theoretical imports largely enhanced the understanding of planning as an intersubjective and communicative enterprise, 
questions of the embodied and sensing nature of the planning practice were still out of focus.

The evident downside of this negligence of emotions is that our understanding of planning practice within this frame of reasoning must be necessarily limited. "There are many aspects of the practical art of planning that we do not understand because analysts have overlooked how emotions and feelings shape the plans people make individually as urban dwellers or urban planners" (Hoch, 2006, p. 380). For example, the absence of emotions in planning discourse, as well as the self-image of planners, tends to become a source of superiority, resulting in a power imbalance between planners and the local population. By ascribing emotions only to the latter group, "their knowledge cannot count as knowledge for it is too intimately grounded in, and tainted by, their (essential) corporeality" (Longhurst, 1997, p. 494). This artificial distinction of a political sphere and a body/subject sphere (Anderson, Smith, 2001, p. 9) consequently leads to a depolitization of emotions. By disregarding the feeling and sensing body/ subject as being the base of any perception - including those of planning professionals - planning discourse has so far left out the chances of a more adequate and comprehensive understanding of how planning decisions occur.

\section{Introducing the concept of atmospheres to urban planning research}

The self-image of planners as impartial professionals, as well as their daily practice of working with maps and plans, seems to marginalize all atmospheric sensing. The "cartographic silence" (Harley, 1988, p. 58, cited in Sullivan, 2011, p. 90) seems to effectively segregate them from the lived life of the urban fabric. Nevertheless, if this convention is empirically investigated, the picture becomes more ambiguous and complex as the interview statement of one of the landscape planners of the Tempelhof airfield illustrates:

Before May $8^{\text {th }}$ [of 2010; the day the former airfield opened as a public park] our office was in this small building on-site. And we had a totally different impression of the terrain, just a different feeling. [...] No one was there, but a few construction workers. And we thought: 'well, not sure if anyone will come at all once the park is open'. [...] And I must admit, from May $8^{\text {th }}$ on (...) it was still the same situation of us working in that building and looking out of the window. But now we had a totally different feeling about the terrain. Because now there were people. Because people were passing the window riding their bikes. Because now there were people flying a kite and mothers with their children. Since that very day, the terrain somehow has had a different character to me. I can't describe it (...) it's just a feeling (...) and it is not objective and all, but suddenly it was different than before ${ }^{4}$.

The landscape planner evidently tries to articulate his atmospheric perceptions of the Tempelhof airfield, struggling to find the right words. According to Hasse (2002b), our language lacks proper expressions for the sensing, atmospheric realm. Rather, the "stammering of a whole culture reflects the shadow of a rationalisticly, objectivisticly and positivisticly partial cultivation of an impaired command of language" (ibid., p. 26) . In his attempt to describe the terrain of the Tempelhof airfield, the cited planner in fact describes the atmospheres he is perceiving. This becomes evident as he remarks that the place - without having changed physically - feels different before and after the opening of the park. Even with no people in sight of his office window, the terrain still 
feels different than before being opened (Mackrodt, 2019, p. 2). This supports the idea that the "primary subject-matter of perception are atmospheres. [...] Atmospheres apparently are what is experienced in the bodily presence of man and objects, and in space respectively" (Böhme, 1995, p. 30, p. 47f) 6 .

The empirical episode of the landscape planner draws attention to a defining characteristic of atmospheres, which is of importance to planning research: the relevance of the bodily presence and locatedness for any perception. "In order to have an experience of urban space, we have to be there, we have to have a bodily experience of something that is not a mere representation" (Lapintie, 2007, p. 43, emphasis in original). Edward Casey (2001, p. 689) specifies this co-constituting character of place and self by stating: "[j]ust as there is no implaced self except as a body/self, there is no place either without such a self." He highlights the atmospheric truth that the very idea of a place without a perceiving self is misleading. All of our reasoning and doing takes place somewhere: "being inevitably requires a place, a situation for its disclosure" (Larsen, Johnson, 2012, p. 633). Even activities such as day-dreaming or using Twitter take place somewhere. Consequently, "our actions and words might not be determined by the places in which they occur, but they are certainly influenced by them" (Beauregard, 2013, p. 13). This simple but momentous truth has been neglected in planning discourse and needs to be considered for a more thorough understanding of how planning decisions are made.

11 However, the situativeness of atmospheric perception does not imply that atmospheres are determined by any spatial environment. Their perception is equally dependent on the subjectivity of perception, as Griffero's example of an oak tree has shown. With atmospheres being neither a character of space nor solely a projection of the self, "[i]tt is rather unclear where to locate them: should they be attributed to the objects and environment they seem to stem from, or should they be attributed to the subjects experiencing them" (Böhme, 1995, p. 22)7. Rather, atmospheres are "something that has to be felt as the copresence of subject and object." (Bille, Bjerregaard, Sørensen, 2015, p. 31). It is their very in-betweenness between the material and the immaterial, between subject and object that accounts for the "ontological placelessness" (Böhme, 1995, p. 31) ${ }^{8}$ of atmospheres. Despite this definitory ambiguity, their impact on our decisionmaking and assessment of our environment is more than real. Therefore, their ontological uncertainty should not seduce us to disregard them as genuine subjects of inquiries (Bille, Bjerregaard, Sørensen, 2015, p.33). Rather, atmospheres are omnipresent and touch us in a subtle and sensing way, informing our alleged neutral and objective decision-making.

12 The epistemological benefit of adapting the concept of atmospheres to questions of spatial perceptions - especially in urban studies - has been increasingly recognized (Bille Bierregaard, Sørensen, 2015; Buser, 2014, 2017; Edensor, 2012; Frers, 2007, 2013; Göbel, 2015; Hasse, 2002b, 2012; Kazig, 2007, 2012; Manz, 2015; Michels, 2015; Thibaud, 2015; Wylie, 2005). With the growing academic interest in atmospheres, a new diversity in theoretical concepts has developed. The originally phenomenological approach represented for example by Schmitz (2014), Böhme (1993, 1995), Hasse (2012) and Griffero (2014) has been complemented by a mainly non-representational approach pursued by for example Anderson (2009) and Buser (2014). Anderson (2009) defines affective atmospheres as "a class of experience that occur before and alongside the formation of subjectivity, across human and non-human materialities, and in-between 
subject/object distinctions" (ibid., p. 78). The term affective atmospheres, intrinsically linked to non-representational theory, has become an established idea within the academic, especially English-speaking discourse (Buser, 2014, Closs Stephens, 2016, Edensor, 2012, Michels, 2015). As Winz (2018) has shown, these two sub-discourses can be fruitfully combined. At the same time, the conceptual split of atmospheric discourses has prompted new signs of dissociation in a rather small academic community (Griffero, 2014, p. 35). The atmospheric concept pursued in this article relies on the phenomenological approach and does not discuss further the different nuances of the two sub-discourses sketched out above.

\section{How to research atmospheres in planning practice}

13 The simultaneousness of a sensing body/self and a place is the starting point for any methodological consideration of researching atmospheres. The central unit of investigation therefore is the situation as Griffero illustrates (2014, p. 121): "In a holistic joyful atmosphere, the joy is not so much my joy, but rather a joyous situation, in which the subject and the object are not independent and isolable parts." Consequently, it is "not the action of a subject that needs to be focused on but rather the situation of the moment, the event in its very own evolution and elusiveness" (Hasse, 2010, p. 65)'.

14 This co-constituting character of atmospheres implicates certain methodological requirements that are not easily to be fulfilled. On the one hand, observational methods, such as videography (Heath, 1997; Heath, Hindmarsh, 2002; Lorimer, 2010), visual ethnography (Pink, 2004; Schurr, 2012) or photo-documentation (Markwell, 2000; Oldrup, Carstensen, 2012) allow for capturing the situativeness and immediate presence of atmospheric perception. Observation methods focus on the material and temporal perceiving of atmospheres. At the same time, the interpretation of visual data cannot fully reconstruct the subjective feeling and sensing of the people observed. "The interpretation [of video sequences and photographs] must be modestly limited to what is actually shown, even if further, more general deductions are tempting" (Frers, 2007, p. 23) ${ }^{10}$. Additionally, the observation of the physical environment does not allow for a deduction of the atmospheric impact they have. Rather, "[a]tmospheres refer to objects that create a particular place in space. But their sensible impact cannot be causally ascribed to a quality completely inherent to these objects" (Hasse, 2002b, p. 24) ${ }^{11}$. As challenging as these methodological implications may be, from an epistemological point of view, this is a beneficial limitation that needs to be respected. Without a thorough consideration of the methodological limits of observing atmospheres, the criticism of a new type of geodeterminism on a micro-level could easily be raised (Kazig, 2007, p. 179).

On the other hand, language-based methods such as interviews allow for thorough access to the subjective, emotional perceptions of atmospheres. These methods generally address atmospheres in retrospect. Thereby, the immediate presence of the situation gets lost. Especially in non-representational theory this assumed limitation of interviews has been strongly criticized (Lorimer, 2005, p. 87; Thrift, Dewsbury, 2000, p. 424). This critique has been addressed by the methodological innovation of in-situ interviews. These have been introduced as go-along interviews (Burns, Gallant, Fenton et al., 2019), walking interviews (Evans, Jones, 2011) or commented city walks (Thibaud, 
2013). For the research group of planning officials, these walk-along methods have proven to be unfeasible as will be shown below.

Whether an interview is being conducted in situ or not, from a phenomenological point of view, interview data contains valuable information on the perception of atmospheres. Kazig (2012, p. 95) has called these verbal expressions of atmospheric perception "environmentally-aesthetic episodes" 12 . Such episodes can be identified by paying close attention to anecdotes within an interview that are emotionally relevant to the interviewee (e.g. Crouch, 2003; Fields, 2011; Richter, 2015).

The statement of the landscape planner at the Tempelhof airfield (see previous section) is a characteristic example of this effect. His emotional involvement in the situation of watching park visitors passing by his window becomes evident through his lack of proper words to describe his experience. As long as Western society is missing an "alphabet of our sensing corporality"13 (Hasse, 2002a, p. 78), nonverbal expressions or even stammering related to spatial experiences provide a valuable proxy to atmospheric perception.

"The memories told by the interviewed persons represent moments that are meaningful for them precisely because they are linked emotionally to their [personal experience]. It is not in vain that they recall these moments. [...] Looking at emotions helps to identify crucial moments in the data" (Richter, 2015, p. 146f.).

From the range of methodological approaches to atmospheres, the empirical setting in this case study called for a focus on interview data for two reasons. First, the mere number of on-site experiences by the planning officials was very small. One of the planning officials I interviewed reflects this fact as follows:

"Well, I am having the view on the park from my office window, sure. But, I am not on-site a lot. I wished I had more time just to take a walk around [...]. But there is just too much paperwork to do."14

As part of their professional obligations, the planning professionals seldomly visit the former airfield relying mostly on two-dimensional maps and plans when thinking about the planning site. A second empirical constraint has been the limited access to the on-site visits of planning officials due to the exclusive character of these internal meetings. Therefore, the most feasible empirical approach was conducting interviews (with 11 planning officials) at their work place. By speaking at length about the planning process and the airfield in their daily surrounding of the planning office, I became part of their regular working atmosphere while simultaneously encouraging my interview partners to share 'environmentally-aesthetic episodes' of their atmospheric perception of the Tempelhof airfield, the site they were dealing with constantly.

\section{How the 'unobtrusive obtrusiveness' of atmospheres informs planning decisions}

"[W]e are already within and part of the world we study. It is not possible to sustain an objective and detached view of the world. Geographical understanding always begins from or is relative to a given location in space. The space which is being studied" (Rodaway, 1994, p. 8f.).

This basic condition of any knowledge production can be impressively observed in the planning for the former Tempelhof airfield. Therefore, the first question to be asked and answered is where the planners in charge of this project are situated in space when 
dealing with the Tempelhof airfield. Their specific spatial detachment translates into a certain perspective on the airfield as Merleau-Ponty points out:

"All knowledge takes its place within the horizons opened up by perception" (1962,

p. 241).

The planners' knowledge of the Tempelhof airfield has been mainly informed by their view on the field from within the airport building. This building with a length of more than one kilometer was constructed during the Nazi regime and is to this day one of the longest buildings in Europe. It is located in the northwestern edge of the airfield. Since the closing of the airport in 2008, it has also been the place of business of two companies - founded and owned by the city of Berlin - Grün Berlin and Tempelhof Projekt - whose task has been to maintain and develop the park (Grün Berlin), as well as to promote housing as well as commercial development of the site (Tempelhof Projekt). The municipal planners involved with the planning process have been in close and regular contact with the companies' associates as this interview excerpt illustrates:

Interviewer: Are you regularly on-site?

Planner: Well, you may say, I am on the field, because the offices of Grün Berlin are located right there within the airport building. And we have meetings there quite regularly. Tempelhof Projekt's offices are also located there, but Grün Berlin has this wonderful meeting room with a nice view over the field. Insofar, I very much enjoy having meetings there ${ }^{15}$.

Looking from the northwestern edge onto the airfield produces a specific constellation of here and there, of closeness and distance for this planner as well as his colleagues. Whereas the adjacent neighborhood in the west (Tempelhof) necessarily becomes part of the planners' regular routes in order to get to their workplace, the neighborhood of Neukölln, which borders on the airfield in the opposing eastern edge, remains alien to most planners.

Planner: Back there at the Oder street [at the eastern edge of the airfield] there is this outdoor project, where they show kids how to build huts from recycling material. These kids learn how to use a hammer, nails or a screwdriver ${ }^{16}$.

The described project has been part of the Senate Department's effort to vitalize the park by offering designated lots to mostly non-profit projects close to the three main entrances of the park in the west (Tempelhof neighborhood), north (Kreuzberg neighborhood) and east (Neukölln neighborhood). By describing the project's location as 'back there' the planner reveals where he himself is located and where his 'here' based on the idea of his "sensing body as the point of origin for all orientation" (Günzel, 2007, p. 76) ${ }^{17}$ - is located. The eastern edge of the airfield is being alienated as terra incognita due to its corporal distance of the planners.

This characteristic planners' perspective, looking from west to east has become manifest in the subsequent planning decisions. The alienation of the eastern parts of the airfield first became evident in the park opening in May 2010. The festivities, organized by the Senate Department for Urban Development, included a public run, a speech of the Mayor of Berlin as well as an entertainment program with several booths. What is striking here is the location of these events. The mayor's speech and the starting and finishing line of the run were located at the western main entrance. Other stages and booths were distributed in the northwestern part of the airfield alongside the airport building. In contrast, at the eastern main entrance, no stages or events were located (see illustration 1). 


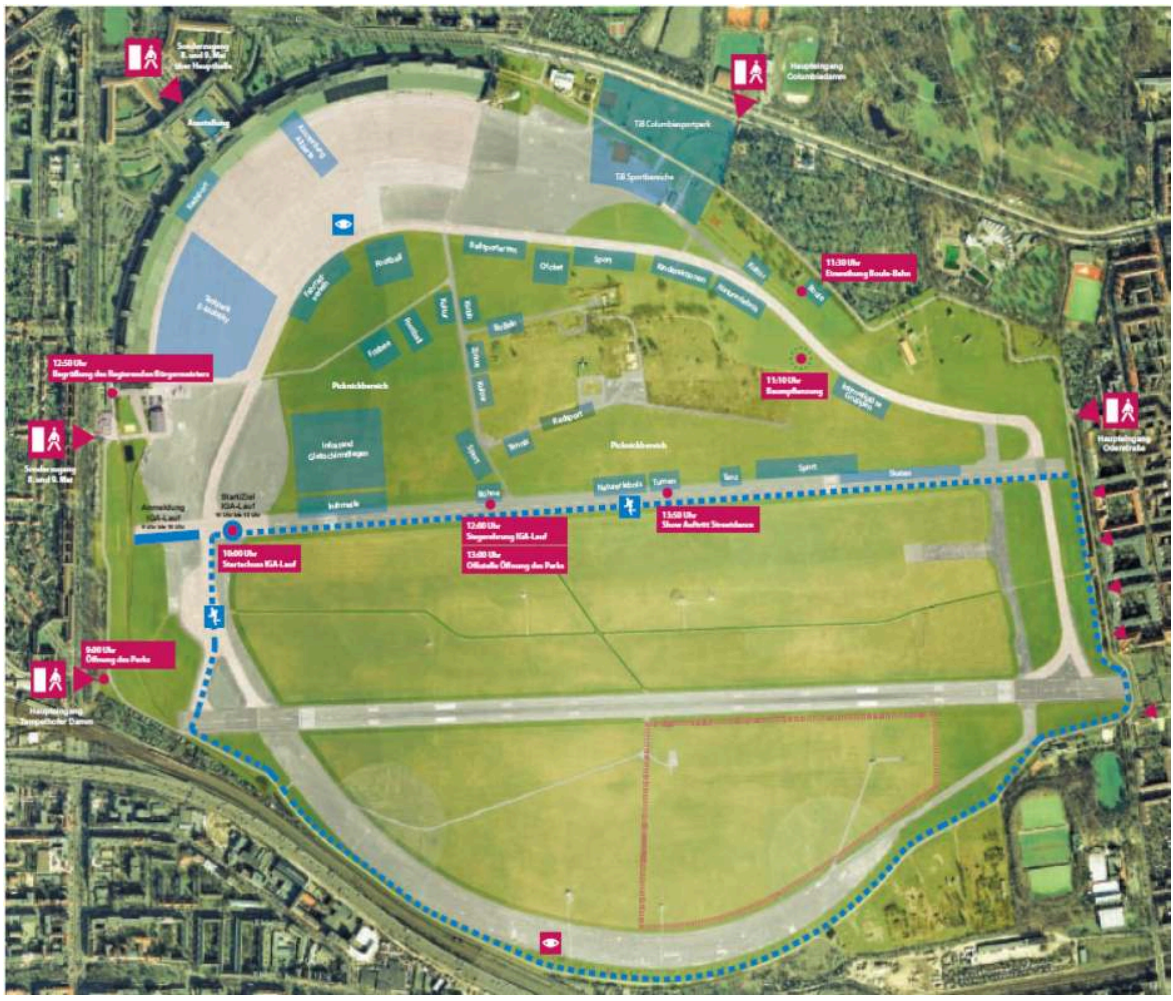

source: Grün Berlin, 2010, p. 1. ㄷ Grün Berlin GmbH 
Illustration 2: winning concept of the landscape planning competition "Parklandschaft Tempelhof" by gross.max

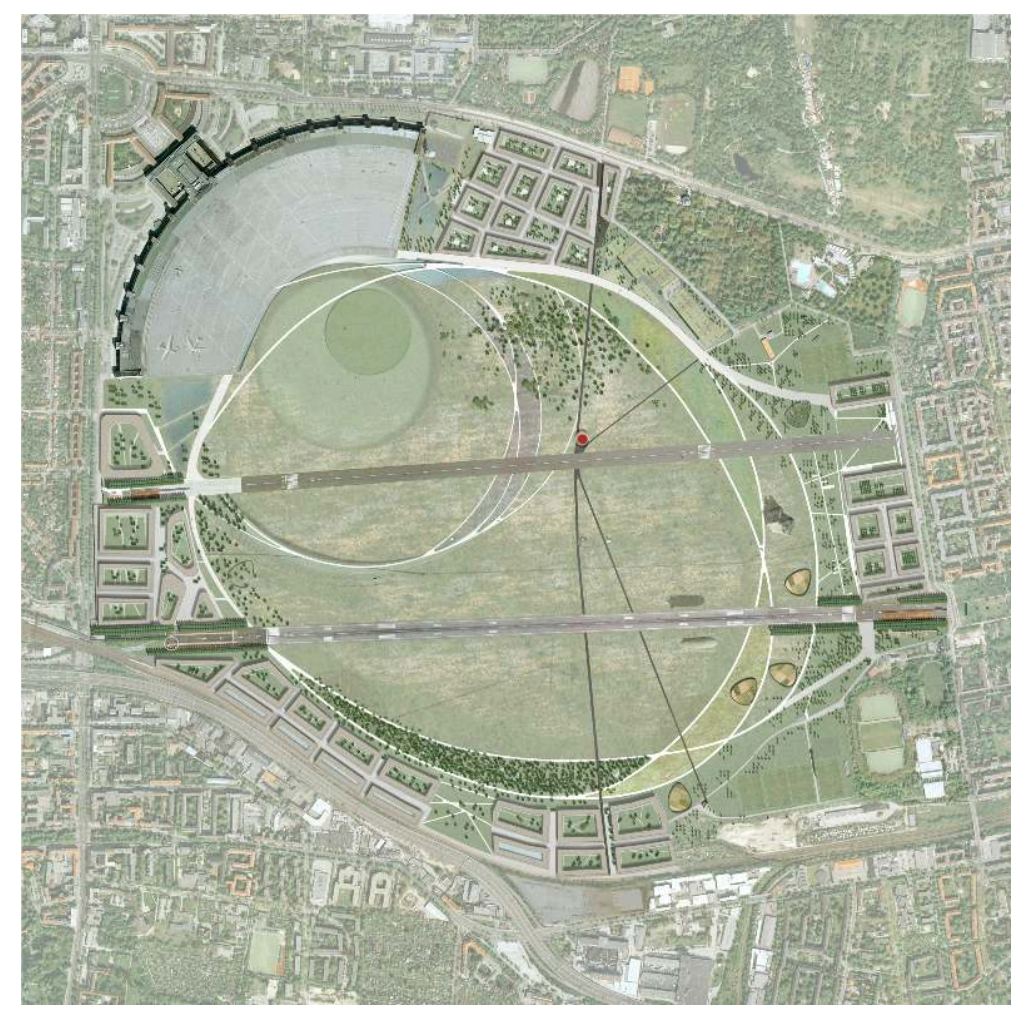

source: gross.max, n.d. @ gross.max

\section{Discussion: Why missing an atmospheric competence matters}

As much as the planners' appreciation of the airfield is informed by their corporal and placed being-in-the-word, so has been the appreciation of the public park by its visitors since its opening in 2010. With more than one million visitors after only a few months, the park quickly became a highly appreciated public space.

Strikingly, the dominant pattern of the public's atmospheric perception of the field has differed fundamentally from that of the planning officials. The following excerpt from one of Berlin's main local newspapers exemplarily demonstrates the field's predominant atmospheric perception (Lange, 2015, n. pag.):

We have just entered the former airfield, and immediately, we can sense this magical gasp of relief. Our views fly over the vast terrain - it is just wonderful to have my view not being blocked every few meters by just another wall. With every step further into the grassland our everyday troubles become smaller and feel more distant than before ${ }^{19}$.

This personal account of a local journalist resonates with several similar accounts of different interviewees as well as the author's own field work (Mackrodt, 2019, p. 78 and ff. $)^{20}$. The quote impressively describes what atmospheres do to us. The absence of a material environment on the plain terrain of the airfield allows for a wide view up to the horizon, going along with a gasp of relief. The transition from the block structure 
of the inner-city neighborhood to the plain airfield brings to bear the characteristic atmospheric dimension of expansion and vastness:

"We experience the feeling of an all-round expansion for example when we enter a high forest with a liberating gasp or an unexpectedly captivating hall. Automatically, we widen our chest and straighten up, just as if we tried to adapt to and to prove being worthy of the impressive surrounding" (Schmitz, 2014, p. 94) ${ }^{21}$.

With the field being void of a materialized third dimension the immaterial powers of wind, light, smell and sound are accentuated. Although atmospheric perceptions neither can be generalized nor stem from the environment itself, the wide physical setting of the airfield contributes to an intensive experience and the potential formation of "environmentally-aesthetic episodes" (again: Kazig, 2012, p. 95). Just as the positioning of the planning officials towards the field has shown to be group-specific, a main point of origin for the atmospheric perception of the group of park visitors can be located around the eastern park entrances. The park monitoring, which was conducted by Grün Berlin annually from 2010 to 2014, quantitatively supports this assumption. Almost half of all visitors enter the field via the eastern entrance (Grün Berlin GmbH/Senatsverwaltung für Stadtentwicklung und Umwelt Berlin, 2012, p. K6).

This entrance is characterized by a privileged view over the runways resulting from a sloping ground (see illustration 3). Designated areas for urban gardening and public barbecues further contribute to the amenity of this segment of the park.

Illustration 3: view from the eastern entrance to the Tempelhof park

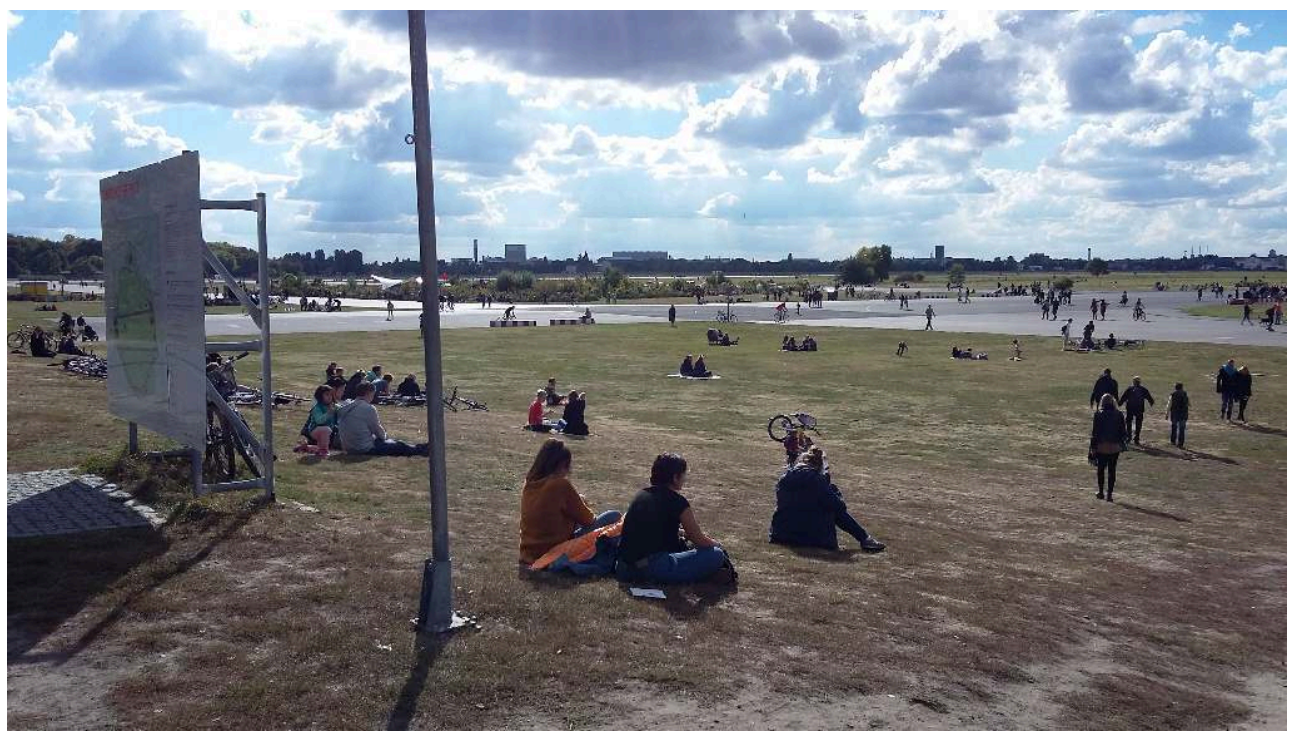

source: Ulrike Mackrodt. (c) Ulrike Mackrodt

By comparing the characteristic atmospheric perceptions of both groups - planners and park visitors - a blatant disconnect becomes evident. Whereas the positioning of planners supports a view from west to east and from inside the airport building onto the airfield, park visitors experience an embodied outdoor presence, looking primarily from east to west. The planners' view from inside "is crucially influenced by the bodily distance from the urban ground. This type of view concentrates all feeling on the 
visible and thinkable. Smell, sounds, the presence of people - all of which remain outside and down there" (Hasse, 2002a, p. 36) ${ }^{22}$.

The contradicting atmospheric truths about the airfield have had a genuine effect on the planning process. As has been shown before, the planning decisions for the park design promoted a plan focusing on the northwestern part of the terrain. In an interview, the winning planner explained: "The circuit is based on the idea of walking on the periphery of the project while repeatedly 'immersing oneself' into the project" 23 (Hooftman, 2011, p. 29). What Hooftman refers to as the periphery are in fact the most frequently used areas close to the park entrances. Moreover, what he assumes to be the center of the park by defining it as the 'inner circle' - "the intensively used zones in front of the airport building" (ibid., p. 32) - is in fact the park areas which are less frequently used. This misinterpretation of here and there, of central and peripheral, was repeated three years later in 2013 regarding the planning for future housing development. Of the three designated development lots, the largest was located at the very eastern entrance where most of the park visitors entered (see illustration 4).

Illustration 4: Masterplan ,Tempelhofer Freiheit‘ 2013

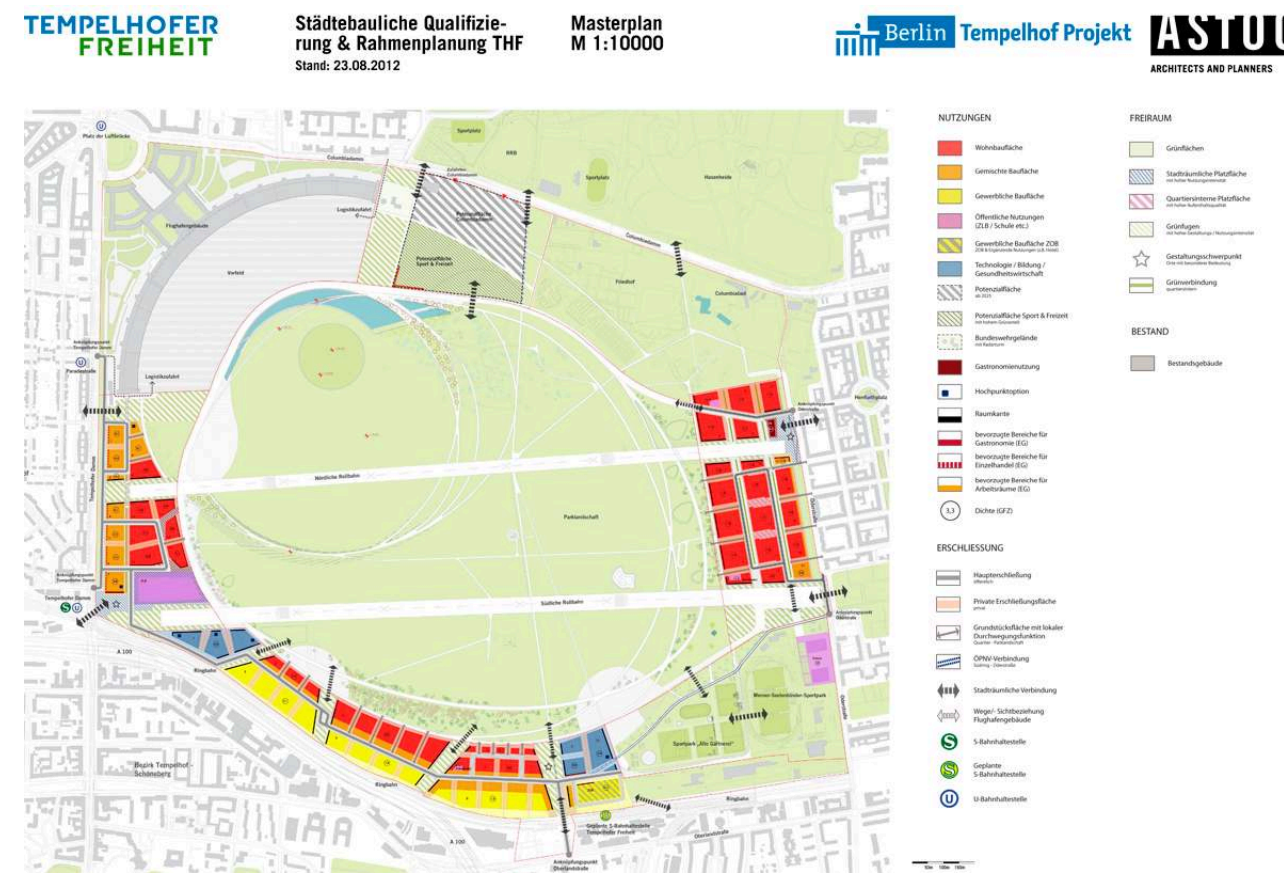

source: Astoc Architects and Planners, n.d. (c) Astoc Architects and Planners

Due to their lack of own embodied knowledge, the planning authorities did not show any consideration for the atmospheric force that was experienced onsite by park visitors. The study's findings indicate that the atmospheric ignorance of planners intensified the planning conflict. Without arguing for a causality (Mackrodt, 2019, p. 58), it has been shown that the political opposition of planning authorities and local inhabitants resonates with their atmospheric opposition. Like in John Godfrey Saxe's poem "The Blind Men and the Elephant", in which blind men stand at different parts of an elephant touching it and cannot agree on what they are feeling, planners and park visitors have had a fundamentally different perception of the airfield. 

embodied and emotional sensing of the environment. Thereby, the paper contributes to planning research by suggesting a self-image for planners that is "intimately grounded in, and tainted by, their (essential) corporeality" (again: Longhurst, 1997, p. 494). It is a call for using the concept of self/body as the point of origin of all deliberation. Subjectivity and emotional accounts in planning practice are not a deficit of the subaltern part within a dichotomic power relation. They are a human precondition. By adopting this approach to planning practice, future conflicts in urban planning may be more adequately dealt with, potentially leading to better planning results.

\section{BIBLIOGRAPHY}

Allmendinger, Philip \& Tewdwr-Jones, Mark. 2002. The Communicative Turn in Urban Planning. Unravelling Paradigmatic, Imperialistic and Moralistic Dimensions. Space \& Polity. vol. 6, $\mathrm{n}^{\circ} 1$, p. 5-24.

Anderson, Ben. 2009. Affective atmospheres. Emotion, Space and Society. vol. 2, n 2, p. 77-81.

Anderson, Kay \& Smith, Susan J. 2001. Editorial: Emotional geographies. Transactions of the Institute of British Geographers. vol. 26, $n^{\circ}$ 1, p. 7-10.

Astoc Architects and Planners. Köln: Städtebau. Available online at: https://www.astoc.de/de/ projekte/staedtebau (consulted September 30, 2019).

Beauregard, Robert. 2013. The neglected places of practice. Planning Theory \& Practice. vol. $14, \mathrm{n}^{\circ} 1$, p. 8-19.

Bille, Mikkel; Bjerregaard, Peter \& Sørensen, Tim F. 2015. Staging atmospheres: Materiality, culture, and the texture of the in-between. Emotion, Space and Society. vol. 15, p. 31-38.

Böhme, Gernot. 1993. Atmosphere as the Fundamental Concept of a New Aesthetics. Thesis Eleven. vol. 36, p. 113-126

Böhme, Gernot. 1995. Atmosphäre. Essays zur neuen Ästhetik. Frankfurt am Main: Suhrkamp.

Burns, Robyn; Gallant Karen A; Fenton, Lara; White, Catherine \& Hamilton-Hinch, Barb. 2019. The go-along interview: a valuable tool for leisure research. Leisure Sciences. An Interdisciplinary Journal [online]. vol. 42, $\mathrm{n}^{\circ}$ 1. Available online at: https://www.tandfonline.com/doi/full/ 10.1080/01490400.2019.1578708?scroll=top\&needAccess=true (consulted on September 30, 2019).

Buser, Michael. 2014. Thinking through non-representational and affective atmospheres in planning theory and practice. Planning Theory. vol. 13, n 3, p. 227-243.

Buser, Michael. 2017. Atmospheres of stillness in Bristol's Bearpit. Environment and Planning D. Society and Space. vol. $35, \mathrm{n}^{\circ} 1$, p. 126-145.

Casey, Edward S. 2001. Between Geography and Philosophy: What Does It Mean to Be in the PlaceWorld? Annals of the Association of American Geographers. vol. 91, nº 4, p. 683-693. 
Closs Stephens, Angharad. 2016. The affective atmospheres of nationalism. Cultural Geographies. vol. 23, n², p. 181-198.

Crouch, David. 2003. Spacing, performing, and becoming: tangles in the mundane. Environment and Planning A. vol. 35, n 11, p. 1945-1960.

De Certeau, Michel. 1990. L'invention du quotidien. Tome 1 : Arts de faire. Paris: Gallimard.

Edensor, Tim. 2012. Illuminated Atmospheres. Anticipating and Reproducing the Flow of Affective Experience in Blackpool. Environment and Planning D: Society and Space. vol. $30, \mathrm{n}^{\circ} 6$, p. 1103-1122.

Evans, James \& Jones, Phil. 2011. The walking interview: Methodology, mobility and place. Applied Geography. vol. 31, n², p. 849-858.

Ferreira, Antonio. 2013. Emotions in planning practice: a critical review and a suggestion for future developments based on mindfulness. Town Planning Review. vol. 84, $\mathrm{n}^{\circ}$ 6, p. 703-719.

Fields, Desiree. 2011. Emotional refuge? Dynamics of place and belonging among formerly homeless individuals with mental illness. Emotion, Space and Society. vol. 4, n 4, p. 258-267.

Frers, Lars. 2007. Einhüllende Materialitäten: Eine Phänomenologie des Wahrnehmens und Handelns an Bahnhöfen und Fährterminals. Bielefeld: Transcript.

Frers, Lars. 2013. The matter of absence. Cultural Geographies. vol. 20, n 4, p. 431-445.

Giddens, Anthony. 1984. The Constitution of Society. Cambridge: Polity Press.

Göbel, Hanna K. 2015. The re-use of urban ruins. Atmospheric inquiries of the city. New York: Routledge.

Griffero, Tonino. 2014. Atmospheres. Aesthetics of emotional spaces. Burlington: Ashgate Pub. gross.max. Edinburgh: projects/parks. Available online at: http://www.grossmax.com/ projects.asp?n=Parks\&x=4\&offset=0 (consulted on September 30, 2019).

Grün Berlin GmbH. 2010. Plan Eröffnungsfest Tempelhofer Feld Presse. Berlin.

Grün Berlin GmbH/Senatsverwaltung für Stadtentwicklung und Umwelt Berlin. 2012. Tempelhofer Freiheit: Besuchermonitoring 2012. Ergebnisse. Berlin.

Günzel, Stephan. 2007. Maurice Merleau-Ponty. Werk und Wirkung: Eine Einführung. Wien: Turia + Kant.

Habermas, Jürgen. 1983. The Theory of Communicative Action. Boston: Beason Press Boston.

Harley, Brian J. 1988. Silences and secrecy: the hidden agenda of cartography in early modern Europe. Imago Mundi. vol. 40, nº 1, p. 57-76.

Hasse, Jürgen. 2002a. Die Atmosphäre einer Straße. Die Drosselgasse in Rüdesheim am Rhein. In: Hasse, Jürgen (ed.). Subjektivität in der Stadtforschung. Frankfurt am Main: Institut für Didaktik der Geographie. p. 61-114.

Hasse, Jürgen. 2002b. Zum Verhältnis von Stadt und Atmosphäre. Wo sind die Räume der Urbanität? In: Hasse, Jürgen (ed.). Subjektivität in der Stadtforschung. Frankfurt am Main: Institut für Didaktik der Geographie. p. 19-40.

Hasse, Jürgen. 2010. Raum der Performativität. “Augenblicksstätten” im Situationsraum des Sozialen. Geographische Zeitschrift. vol. 98, n² 2, p. 65-82.

Hasse, Jürgen. 2012. Atmosphären der Stadt. Aufgespürte Räume. Berlin: Jovis. 
Healey, Patsy. 1996. The communicative turn in planning theory and its implications for spatial strategy formation. Environment and Planning D: Society and Space. vol. 23, n 2, p. 217-234.

Heath, Christian. 1997. The analysis of activities in face to face interaction using video. In: Silverman, David (ed.). Qualitative research. Theory, method, and practice. London/Thousand Oaks, California: Sage. p. 183-200.

Heath, Christian \& Hindmarsh, Jon. 2002. Analysing interaction: Video, ethnography and situated conduct. In: May, Tim (ed.). Qualitative Research in Action. London: Sage. p. 99-121.

Hoch, Charles. 2006. Emotions and Planning. Planning Theory \& Practice. vol. 7, n 4, p. 367-382.

Hooftman, Eelco. 2011. Urban agriculture ist ein heikles Stichwort. Eelco Hooftman im Gespräch mit Kaye Geipel und Doris Kleilein. Bauwelt. vol. 36.2011, p. 26-34.

Kazig, Rainer. 2007. Atmosphären - Konzept für einen nicht repräsentationellen Zugang zum Raum. In: Pütz, Robert \& Berndt, Christian (eds.). Kulturelle Geographien. Zur Beschäftigung mit Raum und Ort nach dem Cultural Turn. Bielefeld: Transcript. p. 167-187.

Kazig, Rainer. 2012. Konturen einer situativen Umweltästhetik. Geographische Zeitschrift. vol. 100, $\mathrm{n}^{\circ} 2$, p. 84-102.

Lange, Nadine. 2015. Wo die Junikäfer ins Bier plumpsen. Der Tagesspiegel. 24.07.2015.

Lapintie, Kimmo. 2007. Modalities of Urban Space. Planning Theory. vol. 6, n 1, p. 36-51.

Larsen, Soren C \& Johnson, Jay T. 2012. Toward an Open Sense of Place: Phenomenology, Affinity, and the Question of Being. Annals of the Association of American Geographers. vol. 102, $\mathrm{n}^{\circ} 3$, p. 632-646.

Lefebvre, Henri. 1991. The production of space. Malden, Mass.: Blackwell.

Longhurst, Robyn. 1997. (Dis)embodied geographies. Progress in Human Geography. vol. 21, n 4 , p. 486-501.

Lorimer, Hayden 2005. Cultural geography: the busyness of being 'more-than-representational' Progress in Human Geography. vol. 29, n 1, p. 83-94.

Lorimer, Jamie. 2010. Moving image methodologies for more-than-human geographies. Cultural Geographies. vol. 17, n² 2, p. 237-258.

Mackrodt, Ulrike. 2019. Die Atmosphären des Tempelhofer Feldes: Zum Einfluss raumbezogener Emotionen auf die Planung öffentlicher Räume [online]. PhD thesis. Berlin: Humboldt-Universität zu Berlin. Availabe online at: https://edoc.hu-berlin.de/bitstream/handle/18452/20716/ dissertation_mackrodt_ulrike.pdf?sequence=3\&isAllowed=y (consulted on September 30, 2019).

Manz, Katja. 2015. Sichtbares und Unsichtbares: RaumBilder und Stadtplanung - ein Perspektivenwechsel. In: Schlottmann, Antje \& Miggelbrink, Judith (eds.). Visuelle Geographien. Zur Produktion, Aneignung und Vermittlung von RaumBildern. Bielefeld: Transcript. p. 133-145.

Markwell, Kevin W. 2000. Photo-Documentation and Analyses as Research Strategies in Human Geography. Australian Geographical Studies. vol. 38, n 1, p. 91-98.

Merleau-Ponty, Maurice. 1962. Phenomenology of Perception. London: Routledge \& K. Paul Humanities Press.

Michels, Christoph. 2015. Researching affective atmospheres. Geographica Helvetica. vol. 70, p. 255-263. 
Nuissl, Henning \& Heinrichs, Dirk. 2011. Fresh wind or hot air? What spatial planning can gain from the governance discourse. Journal of Planning Education and Research. vol. 31, n 1, p. 47-59.

Oldrup, Helene H \& Carstensen, Trine A. 2012. Producing geographical knowledge through visual methods. Geografiska Annaler: Series B, Human Geography. vol. 94, n³ 3, p. 223-237.

Pink, Sarah. 2004. Doing Visual Ethnography. London: Sage.

Richter, Marina. 2015. Can you feel the difference? Emotions as an analytical lens. Geographica Helvetica. vol. 70, p. 141-148.

Rodaway, Paul. 1994. Sensuous geographies. Body, sense and place. London: Routledge.

Sager, Tore. 1994. Communicative Planning Theory: Rationality versus Power. Brookfield: Avebury Press.

Salet, Willem; Thornley, Andy \& Kreukels, Anton (Eds.). 2007. Metropolitan governance and spatial planning. Comparative case studies of European city-regions. London: Spon Press.

Schmitz, Hermann. 2014. Atmosphären. Freiburg im Breisgau: Verlag Karl Alber.

Schurr, Carolin. 2012. Visual ethnography for performative geographies: how women politicians perform identities on Ecuadorian political stages. Geographica Helvetica. vol. 67, p. 195-202.

Sehested, Karina. 2009. Urban Planners as Network Managers and Metagovernors. Planning Theory \& Practice. vol. 10, $\mathrm{n}^{\circ} 2$, p. 245-263.

Sullivan, Robert E. 2011. Geography speaks. Performative aspects of geography. Farnham, Surrey, England/Burlington, VT: Ashgate.

Thibaud, Jean-Paul. 2013. Commented City Walks. Wi: Journal of Mobile Media [online]. Available online at: http://wi.mobilities.ca/commented-city-walks/ (consulted on September 30, 2019).

Thibaud, Jean-Paul. 2015. The backstage of urban ambiances: When atmospheres pervade everyday experience. Emotion, Space and Society. vol. 15, p. 39-46.

Thrift, Nigel \& Dewsbury, John-David. 2000. Dead geographies - and how to make them live. Environment and Planning D: Society and Space. vol. 18, n 4, p. 411-432.

Winz, Marc. 2018. An atmospheric approach to the city-psychosis nexus. Perspectives for researching embodied urban experiences of people diagnosed with schizophrenia. Ambiances [online]. Available online at: http://journals.openedition.org/ambiances/1163 (consulted on September 30, 2019).

Wylie, John. 2005. A single day's walking: narrating self and landscape on the South West Coast Path. Transactions of the Institute of British Geographers. vol. 30, n 2, p. 234-247.

\section{NOTES}

1. My translation of the original text: unauffällige Aufdringlichkeit.

2. My translation of the original text: ,kultivierte Segmentierung des Menschen in sogenannnte ,offentliche und ,private Lebenssektoren [...]. Als Akteur scheint er stets nach guten Gründen zu handelnin Wissenschaft, Verwaltung, Rechtssprechung und Gesetzgebung, aber auch im täglichen Leben. Als sinnlicher - gleichsam ,zweiter - Mensch erfreut er sich an den Künsten, gutem Essen, dem Sport, lässt sich therapieren und genießt seine Freizeit. 
3. Nevertheless, the concept of rational planning lives on in the still widely received social theories, such as Henri Lefebvre's Production of Space (1991) or Michel DeCerteau's Arts de faire (1990).

4. My translation of the original text: Vor dem 8. Mai saßen wir da in dem kleinen Gebäude auf dem Feld und das Gelände hatte einen ganz anderen Eindruck auf uns gemacht, so rein vom Gefühl her. [...] Es war kein Mensch da, außer ein paar Bauarbeitern. Und da dachte man schon: ,Naja, ob das überhaupt jemanden interessiert, wenn wir das da öffnen. ' [...] Ja und ich muss sagen, ab diesem Tag, ab dem 8. Mai (...) wir saßen ja immer noch da drin und haben aus dem Fenster geguckt. Und wir haben ein völlig anderes Gefühl gehabt, dieses Gelände betreffend. Weil da eben plötzlich Leute waren. Weil da Menschen mit dem Fahrrad am Fenster vorbeigefahren sind. Weil plötzlich die ersten Leute da waren, die da Drachen haben steigen lassen. Weil, was weiß ich, Mütter mit Kindern da waren. Das Gelände hat für mich persönlich seit diesem Stichtag irgendwie einen anderen Charakter gehabt. Gefühlt (...) kann man nicht beschreiben (...) Ist auch nicht objektiv, aber es war auf einmal anders als vorher.

5. My translation of the original text: Im Stammeln einer ganzen Kultur kommt doch der Schatten einer rationalistisch objektivistisch und positivistisch vereinseitigten Kultivierung eines restringierten Sprachvermögens zum Ausdruck.

6. My translation of the original text: Der primäre Gegenstand der Wahrnehmung sind die Atmosphären. [...] Atmosphären sind offenbar das, was in leiblicher Anwesenheit bei Menschen und Dingen bzw. in Räumen erfahren wird.

7. My translation of the original text: Man weiß nicht so recht, soll man sie den Objekten oder Umgebungen, von denen sie ausgehen, zuschreiben oder den Subjekten, die sie erfahren.

8. My translation of the original text: ontologische Ortslosigkeit.

9. My translation of the original text: Damit rückt nicht die Handlung eines Subjekts in den Mittelpunkt, sondern die Situation des Augenblicks, das Ereignis und das ihm eigene [...] Geschehen in seiner Unverfügbarkeit.

10. My translation of the original text: die Interpretation muss sich auf das bescheiden, was gezeigt wird, [auch wenn die] Verlockung zu darüber hinausgehenden, attraktiv verallgemeinernden Schlussfolgerungen [groß ist].

11. My translation of the original text: Atmosphären beziehen sich auf die Dinge, die im Raum einen spezifischen Ort bilden, lassen sich in ihrer spürbaren Wirkung aber nie kausal auf etwas zurückführen, das in diesen Dingen restlos aufginge.

12. My translation of the original text: umweltästhetische Episoden.

13. My translation of the original text: Alphabet der Leiblichkeit

14. My translation of the original text: Ich guck zwar von meinem Büro aus schon in den Park, das ist klar. Naja, aber ich bin zu selten da, klar. Ich wünschte mir, ich hätte mehr Zeit, da einfach mal eine Runde $z u$ drehen. [...] aber es ist eben zu viel Schreibtischarbeit.

15. My translation of the original text: Sind Sie regelmäßig auf dem Feld? Ich bin insofern, wenn man so will, auf dem Feld, weil Grün Berlin sitzt im Gebäude. Und da gibt es natürlich relativ regelmäßig Termine. Tempelhof Projekt sitzt auch da, aber Grün Berlin hat einen wunderbaren Besprechungsraum mit Blick über das Feld. Und insofern, das genieße ich sehr, wenn wir da Besprechungen haben.

16. My translation of the original text: Ein Pionierprojekt [ist] hinten an der Oderstraße. Das ist so ein Projekt, die bauen mit Kindern zusammen aus Recycling-Material, aus Holzbrettern, Paletten und sowas so Holzhütten auf. Und die Kinder lernen unter Anleitung dann, wie man mit Hammer, Nagel oder Schrauben umgeht.

17. My translation of the original text: Leib als Orientierungsnullpunkt.

18. My translation of the original text: Weil das Flughafengebäude das gesamte Flugfeld räumlich derart kongenial fasst, war der ,Fußabdruck' des Gebäudes für uns klar der Schlüssel zum Entwurf. [...] Man muss eine einfache figurative Form setzen, um das Raumerlebnis zu vermitteln und um die Idee vom Fußabdruck zu verdeutlichen. Das haben wir versucht und nannten das dann, Orbits', Umlaufbahnen oder Kreisbahnen. 
19. My translation of the original text: Kaum haben wir das ehemalige Flughafengelände betreten, setzt dieses magische Aufatmen ein. Der Blick fliegt über die Fläche - es ist einfach wunderbar, wenn er mal nicht alle paar Meter an Häuserfronten abprallen muss. Mit jedem Schritt über die Wiese rückt der Alltagsärger ein Stück weiter in die Ferne.

20. The research design of this study has inherently produced a socio-cultural bias by intentionally focusing on the - mainly middle-class citizens with higher education - participants of the planning process (see also Mackrodt, 2019, p. 44f). This bias needs to be considered regarding generalizations made in the article.

21. My translation of the original text: Das Gefühl einer allseitigen Ausdehnung haben wir u. a. dann, wenn wir mit befreiendem Aufatmen einen Hochwald betreten oder einen unerwartet schönen Saal. Unwillkürlich weiten wir die Brust und machen uns größer, gerade so, als wollten wir uns der imponierenden Umgebung anpassen und würdig erweisen.

22. My translation of the original text: [Diese Position] ist entscheidend von der leiblichen Entfernung vom Boden der Stadt geprägt. Der Blick konzentriert das Gefühl allein auf das Sichtbare und Denkbare. Der Geruch, die Geräusche, [die Anwesenheit] der Menschen - all das bleibt draußen und unten.

23. My translation of the original text: Der Rundgang basiert auf der Idee, dass man an der Peripherie des Projekts entlangläuft und immer wieder in das Projekt, eintaucht.

\section{ABSTRACTS}

The fundamental subject matter of urban planning is urban space. However, this fact is rarely reflected in planning theory. Instead of dealing with the everyday use of urban space and its atmospheric perception, planning discourse is dominated by theories of action, which primarily focus on communication processes within planning practice. The role of urban space within these planning negotiations is often overlooked. By disregarding the feeling and sensing body/ subject as being the base of any perception - including those of planning professionals - planning discourse has left out the chances of a more comprehensive understanding of how planning decisions occur. The article aims to fill this epistemological gap by applying the concept of atmospheres to the case study of the planning process for the former inner-city airfield Tempelhof in Berlin. Thereby it becomes possible to consider the impact of the - borrowing Gernot Böhme's terminology - 'unobtrusive obtrusiveness' of atmospheres on the controversial planning case of Tempelhof airfield. The empirical findings - based on interview data demonstrate how the planners' atmospheric perception of Tempelhof airfield translates into distinctive, and more importantly, controversial planning decisions. In doing so, the article provides a basis for developing atmospheric competences, which have been absent in urban planning thus far.

Le sujet fondamental de la planification urbaine est l'espace urbain. Cependant, cela est rarement reflété dans la théorie de la planification. Au lieu de traiter de l'utilisation quotidienne de l'espace urbain et de sa perception atmosphérique, le discours sur la planification est dominé par les théories de l'action, qui se concentrent principalement sur les processus de communication dans la pratique de la planification. Le rôle de l'espace urbain dans ces négociations de planification est souvent négligé. En ne tenant pas compte du sentiment et de la perception du corps/sujet comme étant la base de toute perception - y compris celle des professionnels de la planification - le discours sur la planification a laissé de côté l'opportunité d'une compréhension 
plus complète des modes de décision au sein des processus de planification. L'article vise à combler cette lacune épistémologique en appliquant le concept d'atmosphère à l'étude de cas de l'aménagement de l'ancien aéroport du centre-ville de Tempelhof à Berlin. Il devient ainsi possible de considérer l'impact de la terminologie empruntée à Gernot Böhme « d'indiscrétion discrète » des atmosphères sur le cas controversé de l'aménagement de l'aéroport de Tempelhof. Les résultats empiriques - basés sur une méthode mixte de données d'observation et de données discursives - montrent comment la perception subjective des atmosphères de l'aéroport de Tempelhof par les responsables de la planification se traduit par des décisions de planification distinctes et controversées. Ce faisant, l'article fournit une base pour le développement des compétences atmosphériques, ce qui n'a pas été le cas jusqu'à présent dans la planification urbaine.

\section{INDEX}

Mots-clés: ambiances, urbanisme, théorie de l'urbanisme, situativité, Berlin

Keywords: atmospheres, urban planning, planning theory, situativeness, Berlin

\section{AUTHOR}

\section{ULRIKE MACKRODT}

Ulrike Mackrodt holds a PhD in urban geography from the Department of Geography at Humboldt University Berlin. Since finishing her doctorate in 2017 she has been employed as scientific adviser at the Berlin parliament.

E-mail contact: ulrike.mackrodt@alumni.hu-berlin.de 